\title{
Łucjan Siewczyński
}

Dr hab. inż. em. prof. PP

Państwowa Wyższa Szkoła Zawodowa w Gnieźnie, Zakład Budowy Mostów i Dróg

Kolejowych, Instytut Inżynierii Lądowej, Politechnika Poznańska

lucjan.siewczynski@put.poznan.pl

\section{Michał Pawłowski}

Dr inż.

Zakład Budowy Mostów i Dróg Kolejowych, Instytut Inżynierii Lądowej,

Politechnika Poznańska

lmichal.pawlowski@put.poznan.pl

DOI: 10.35117/A_ENG_18_10_04

\section{Ways of identifying the reasons for the lack of full protective layer application effects}

\begin{abstract}
The article presents the most common causes of problems with obtaining the required parameter values of a subgrade with a protective layer during the technical acceptance(the module of base deformation and the density rate). There were discussed in detail various methods of recognition. Pointed the limitations and determinants of the research to recognize the reasons for the lack of the reinforcement effect of the subgrade with the protective layer. Presented methods that eliminates the limitations and problems allowing to obtain full effects of the subgrade reinforcement with the protective layer.
\end{abstract}

Keywords: Railroad; Subgrade; Protective layer

\section{Introduction}

During the reconstruction of the railway track subgrade conducted as part of its modernization or repair, taking into account the current requirements contained in the regulations and standards, and using new methods and work technologies, three main objectives are achieved: improvement of the road condition created in the past, taking into account the currently known construction methods and regulations, removing the effects of many years of exploitation and adaptation of the subgrade to new operating conditions (higher speeds, axial loads and transport, changes in the geometric layout of the road, etc.).The basic modernization or repairing of the subgrade, if it does not show signs of instability in operation, and when there is no change in the geometric layout of the road, is to strengthen its upper zone by applying a protective layer and improving the conditions of dehydration. In most cases, the incorporation of a protective layer is the replacement of used materials and soils constituting the upper zone of the track bed before rebuilding. The new structure, which is made of sublayers made of natural materials or broken stone, if necessary also containing geocomposites, replaces the previous upper zone of the subgrade. The protective layers are made on appropriately prepared subgrade or ground. In special cases, this preparation requires the stabilization of soils with building adhesives [10].In the geotechnical investigation process, using the basic direct methods - boreholes and soil samples as well as auxiliary tests soundings and test loads, the condition of the existing subgrade is recognized. As intermediate, also indirect geophysical methods of track bed testing, e.g. radar, is used.

On the basis of the results of geotechnical investigations, that is, the types and properties of the soil, a substructure remodeling project are prepared, including the type and thickness of 
the reinforcement structure and the required condition of the track bed during and after the work.

During modernization or repair works, including the results of geotechnical tests performed after removal of a part of the existing subgrade, at the level of the protective layer foundation, the design of the layer construction is verified by comparing the land parameters adapted to the project with the real parameters of the reconstructed subgrade. In the event of discrepancies, a correction of the designed layer thickness may be necessary to achieve the required load-bearing capacity of the entire new substructure of the subgrade - the protective layer [11].

Construction works are carried out with the use of typical technologies and general construction earthmoving machinery or a train for track bed repair. During works it is difficult or impossible to remove some of the conditions and defects from the construction period of the trackbed, e.g. due to the use of inappropriate soils, their improper distribution in the crosssection of the track, small soil compaction in embankments, etc.

As a result of the work carried out, the track bed should be characterized by the required loadbearing capacity and the appropriate condition of aggregate and soil compaction. Therefore, after the completion of the reconstruction, geotechnical acceptance tests are carried out, in which the deformation states and compacting of the subgrade are controlled, respectively determined by the values of the secondary deformation module measured on the track and the density indicator of the aggregate of the protective layer. The results of acceptance tests are compared with the required parameter values specified in the regulations [3] and project documentation. The values of the secondary deformation modules and the density indicator are therefore the main, but not the only, acceptance parameters of the subgrade after rebuilding.

In practice, the implementation of protective layers are cases in which, despite the implementation of works in accordance with the design and construction art, it is problematic or even impossible to obtain a subgrade characterized by the required values of deformation modules measured on the track and density indicators of the aggregate layer (geotechnical parameters of the subgrade). These problems most often affect only some points or sections of the subgrade being rebuilt. Determining the reasons for this disadvantage makes it possible to take appropriate measures to eliminate them and, as a result, to obtain a substructure with the desired properties. In the diagnosis of the problem, it turns out that there were a number of minor causes that could not cause complications alone, but their combined effect leads to unfavorable circumstances in which it is difficult or even impossible to obtain the required acceptance parameters and thus the expected deformation and density conditions.

\section{The reasons for the lack of full effects of the reinforcement of the subgrade}

Based on own experience gained during the modernization of railway lines E20, E30 and LK No. $1[4,5,10,12]$, which included reconstruction of the upper zone of the subgrade, an attempt was made to classify the reasons for not fully recovering the subgrade with a protective layer. Twenty reasons were distinguished and described, divided into four sets [8]:

- deterioration of soil and water conditions: occurrence of adverse weather conditions, destructive impact of moving construction equipment along the bedrock, destructive impact of thickening machines, lack of patency of drainage sequences during the works,

- design errors: erroneous or limited recognition of the subgrade's soil properties and layering systems, adoption of incorrect design assumptions, failure to adjust the thickness of the protective layer to the actual soil-water subgrade conditions, design of too small layer thicknesses, 
- implementing errors: measurement errors leading to the achievement of a protective layer of too small thickness, no consideration of the change in layer thickness during its thickening, uneven compaction of the subgrade soil and aggregate protective layer (over the layer length), application to the construction of an aggregate layer with inadequate properties, insufficient condition density of the aggregate layer (on layer thickness),

- construction and executive limitations: from the accuracy of works, no control of the track bed homogeneity in parts of the subgrade pickup with protective layer, reinforcements of high thickness, layers made of sub-layers from various aggregates, reinforcements containing geotextiles, use of the train for subgrade repairs, no effects chemical stabilization of the track bed due to the composition of the mixture or too early anticipation of its effects.

The list of reasons for problems with receiving the reinforcements of the subgrade with division into their separate sets is presented in Table 1.

Tab. 1. Ways of recognition, causes [8] and ways of eliminating [9] problems with obtaining full effects of reinforcing the subgrade with a protective layer

\begin{tabular}{|c|c|c|c|c|}
\hline $\begin{array}{c}\text { Grou } \\
\text { p }\end{array}$ & \multicolumn{2}{|r|}{ Reason } & The way of recognition & Remedial methods \\
\hline \multirow{4}{*}{ 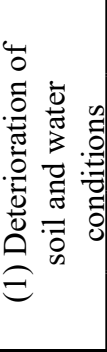 } & 1.1 & $\begin{array}{l}\text { Occurrence of unfavorable weather } \\
\text { conditions }\end{array}$ & \multirow{4}{*}{$\begin{array}{l}\text { Execution of a control ditch } \\
\text { and a macroscopic } \\
\text { assessment of the subgrade } \\
\text { land propertiesRe- } \\
\text { measurement of track bed } \\
\text { deformation modules at the } \\
\text { level of earthworks (in the } \\
\text { control cut) }\end{array}$} & \multirow{4}{*}{$\begin{array}{l}\text { Improving the drainage conditions } \\
\text { of the subgrade. } \\
\text { Repair of the track bed under the } \\
\text { layer }\end{array}$} \\
\hline & 1.2 & $\begin{array}{l}\text { Destructive impact of moving } \\
\text { construction equipment on the } \\
\text { subgrade }\end{array}$ & & \\
\hline & 1.3 & $\begin{array}{l}\text { Destructive impact of thickening } \\
\text { machines }\end{array}$ & & \\
\hline & 1.4 & $\begin{array}{l}\text { No patency of drainage lines during } \\
\text { the works }\end{array}$ & & \\
\hline \multirow{4}{*}{ 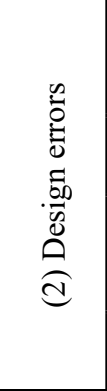 } & 2.1 & $\begin{array}{l}\text { Incorrect or limited recognition of } \\
\text { the properties of the subgrade's soil } \\
\text { and layering systems }\end{array}$ & \multirow{4}{*}{$\begin{array}{l}\text { Ongoing control of the land } \\
\text { properties of the subgrade } \\
\text { during the execution of works } \\
\text { Re-measurement of subgrade } \\
\text { deformation modules at the } \\
\text { level of earthworks }\end{array}$} & \multirow{4}{*}{$\begin{array}{l}\text { Stabilization of the aggregate } \\
\text { layer with hydraulic binders. } \\
\text { Change of protective layer } \\
\text { construction } \\
\text { Repair of the subgrade under the } \\
\text { layer }\end{array}$} \\
\hline & 2.2 & $\begin{array}{l}\text { Adoption of erroneous project } \\
\text { assumptions }\end{array}$ & & \\
\hline & 2.3 & $\begin{array}{l}\text { Not adjusting the thickness of the } \\
\text { protective layer to the actual ground- } \\
\text { water conditions of the subgrade }\end{array}$ & & \\
\hline & 2.4 & $\begin{array}{l}\text { Designing too small layer } \\
\text { thicknesses }\end{array}$ & & \\
\hline \multirow{5}{*}{ 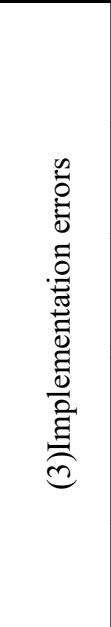 } & 3.1 & $\begin{array}{l}\text { Measurement errors leading to a } \\
\text { protective layer of too small } \\
\text { thickness }\end{array}$ & \multirow{2}{*}{$\begin{array}{l}\text { Execution of a control ditch } \\
\text { and measurement of layer } \\
\text { thickness }\end{array}$} & \multirow{2}{*}{$\begin{array}{l}\text { Change of protective layer } \\
\text { construction }\end{array}$} \\
\hline & 3.2 & $\begin{array}{l}\text { Measurement of errors leading to a } \\
\text { protective layer of too small } \\
\text { thickness }\end{array}$ & & \\
\hline & 3.3 & $\begin{array}{l}\text { Uneven compaction of the subgrade } \\
\text { soil and aggregate of the protective } \\
\text { layer (on the layer's length) }\end{array}$ & $\begin{array}{l}\text { Research on subgrade density } \\
\text { indicators in various } \\
\text { locations }\end{array}$ & Subgrade compactness \\
\hline & 3.4 & $\begin{array}{l}\text { Application for the construction of } \\
\text { an aggregate layer with inadequate } \\
\text { properties }\end{array}$ & $\begin{array}{l}\text { Execution of a control pier } \\
\text { and control of aggregate } \\
\text { properties }\end{array}$ & $\begin{array}{l}\text { Stabilization of the aggregate } \\
\text { layer with hydraulic binders. }\end{array}$ \\
\hline & 3.5 & $\begin{array}{l}\text { Insufficient density of the aggregate } \\
\text { layer (on layer thickness) }\end{array}$ & $\begin{array}{l}\text { Spot evaluation of the layer } \\
\text { density. }\end{array}$ & Replacing layer aggregates \\
\hline 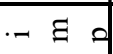 & 4.1 & Accuracy of the works carried out & Execution of a control ditch & Compaction of the track bed \\
\hline
\end{tabular}




\begin{tabular}{|c|c|c|c|}
\hline 4.2 & $\begin{array}{l}\text { Lack of control of the homogeneity } \\
\text { of the track bed in the part of the rail } \\
\text { pickup points with the protective } \\
\text { layer }\end{array}$ & $\begin{array}{l}\text { Execution of a control ditch } \\
\text { and measurement of layer } \\
\text { thickness }\end{array}$ & $\begin{array}{l}\text { Stabilization of the aggregate } \\
\text { layer with hydraulic binders. }\end{array}$ \\
\hline 4.3 & Reinforcements with high thickness & $\begin{array}{l}\text { Execution of a control ditch } \\
\text { and measurement of track } \\
\text { bed deformation modules at } \\
\text { the level of earthworks }\end{array}$ & $\begin{array}{l}\text { Change of protective layer } \\
\text { construction }\end{array}$ \\
\hline 4.4 & $\begin{array}{l}\text { Layers built of sub-layers from } \\
\text { various aggregates }\end{array}$ & $\begin{array}{l}\text { Spot evaluation of the layer } \\
\text { density. }\end{array}$ & \\
\hline 4.5 & $\begin{array}{l}\text { Reinforcements containing } \\
\text { geotextiles }\end{array}$ & Execution of a control ditch & Compaction of the track bed \\
\hline 4.6 & $\begin{array}{l}\text { The use of a train for } \\
\text { dubgraderepairs }\end{array}$ & $\begin{array}{l}\text { Execution of a control ditch } \\
\text { and control of the layer } \\
\text { structure }\end{array}$ & $\begin{array}{l}\text { Stabilization of the aggregate } \\
\text { layer with hydraulic binders. }\end{array}$ \\
\hline 4.7 & $\begin{array}{l}\text { There are no effects of chemical } \\
\text { stabilization of the track bed due to } \\
\text { the composition of the mixture or } \\
\text { too early anticipation of its effects }\end{array}$ & $\begin{array}{l}\text { Execution of a control cross- } \\
\text { section and evaluation of the } \\
\text { geotextile deformability } \\
\text { under load }\end{array}$ & $\begin{array}{l}\text { Change of protective layer } \\
\text { construction }\end{array}$ \\
\hline
\end{tabular}

Ways of recognizing the reasons for the lack of the reinforcement effect of the subgrade When recognizing the causes of problems with obtaining the required values of the acceptance parameters of the track bed, it is often stated that it is not possible to clearly indicate one reason for this condition. It is, therefore, necessary to comprehensively determine the causes of the unfavorable situation that would be possible:

- taking appropriate steps to eliminate them,

- carrying out additional processes improving the subgrade's properties,

- obtaining a subgrade that has the required parameters,

- indication of the potential liability of participants in the construction process for the existing condition.

In order to recognize the causes of problems with obtaining the required values of the acceptance parameters of the track bed with the protective layer, it is recommended:

- analysis of the design of track bed reinforcement and geotechnical documentation,

- conducting an interview with the construction management and analysis of entries in the Construction Log regarding earthworks and methods of building the protective layer,

- re-measuring the deformation of the track bed with the protective layer in close proximity to the place of previous measurements,

- execution of a control ditch to check the structure and thickness of the layer as well as a macroscopic assessment of the land properties of the subgrade,

- measure the track bed deformation modules at the level of earthworks (in the control cut-off),

- check the properties of the aggregate layer on the samples taken,

- evaluation of deformability under the load of the geotextile used.

The aforementioned ways of identifying the reasons for the lack of full effects of 
reinforcing the subgrade with a protective layer are described in detail below. In addition, they are included in table 1, where they are indicated what causes can be identified with their help.

\section{Re-measurement}

In the case of simultaneously finding too small values of the track bed deformation modules with the protective layer and the value of the density indicator or one of these parameters estimated on their basis and in case of doubts as to the correctness of the obtained results, it is recommended to carry out a repeated measurement of the track bed formability in the neighboring location. During measurements, there may be circumstances leading to incorrect and erroneous results. These circumstances include, for example, the wrong way to carry out the markings, technical problems with the test apparatus or erroneous readings from the measuring sensors. It should also be borne in mind that experiments are accompanied by measurement uncertainties whose values depend on the accuracy of the measuring apparatus used [2], and as a result of the measurement ranges of values are obtained in which real values are contained with a given probability.

In the case of estimating indirectly from the results of measuring the deformability of the track bed (based on the value of the deformation index) too small values of the density indicator, its value can be determined by the direct method, e.g. using a sand or water volume meter.

Obtaining too small values of the receiving parameters of the track bed as a result of additional measurement in the neighboring location requires further steps to determine the causes of this situation.

\section{The control ditch}

When the results of carried out measurements of the track bed formability are reliable and unequivocally indicate that the track bed with the protective layer is characterized by too high deformability or improper compaction condition, the reasons for this state can best be determined in destructive tests consisting in making a control cross-section. When making a control ditch, carefully separate the aggregates of individual sub-layers of the protective layer and pay attention not to disturb the ground of the subgrade, and if necessary, also remove fragments of geosynthetics occurring in the construction of the protective layer. Depending on the needs, the size of the control pierce should enable visual assessment and necessary geometrical measurements of the protective layer, measurement of the subgrade's deformability, assessment of the aggregate properties of the subgrade and soil of the subgrade and sampling of aggregates and soils.

After the check-run, the compatibility of the protective layer structure with the design can be assessed by assessing the type and layout of the individual sub-layers of the aggregates and geosynthetics used. Assessment of the compatibility of the protective layer construction with the design should also include determination of the thickness of individual sub-layers. When making a visual assessment of the structure of the protective layer, it is worth paying attention to the homogeneity of aggregate graining in the cross-section of the layer. The inhomogeneity of aggregate graining may be one of the causes of insufficient bearing capacity of the subgrade.

The next stage of identifying the reasons for the lack of required values of the receiving parameters of the subgrade should be a macroscopic assessment of the properties of the subgrade soil and aggregates of the protective layer. In these tests, it is possible to determine the type, humidity, and condition of soil found in the soil bed and applied to the aggregate protective layer. The results obtained can be compared with the design assumptions. The properties of soils and aggregates of the subgrade that are worse than those 
assumed in the project may indicate a potential cause of problems with the acceptance of the subgrade with a protective layer.

Then you can start to measure the deformation of the track bed in the control ditch. Thanks to the measurement of track bed deformation modules, it will be possible to assess the bearing capacity of the subgrade, and thus to assess whether the applied protective layer construction is sufficient to obtain the expected effects of the track bed reinforcement. The measuring plate should be placed at the bottom of the control cross-section - on the exposed but undamaged structure - the subgrade soil. In the case of protective layers with significant thicknesses, the measurement may require the use of appropriately adapted measuring equipment or an increase in the size of the inspection cross-section. Obtained results of the measurement can be compared with the results of measurements carried out before the layer was installed. Additionally, taking into account the existing thickness of the protective layer, the value of the second module of the substructure deformation under the layer can be used to check the correctness of the design assumptions or to determine the expected real reinforcement effects. For this purpose, you can use the relevant graphs $[6,7]$.

After measuring the deformability of the subgrade, soil samples and aggregate layers can be taken to assess their properties in laboratory tests. The minimum scope of laboratory tests should include determining the type, condition, and graining of soils and aggregates found in the subgrade. For a full assessment of the possible reasons for the lack of the reinforcement effect of the subgrade, it may be necessary to perform subgrade soil tests with the determination of their type, humidity and condition not only in the near-surface part of the subgrade but also in its deeper parts.

The deformation of the subgrade with the protective layer may also be negatively influenced by the protective layer of geosynthetics used in the construction. The use of thick geotextiles with considerable deformability may adversely affect the track bed deformation values obtained on the track [1]. If in doubt, the influence of the applied geosynthetics in the construction of the protective layer on the obtained values of the acceptance parameters of the subgrade can be assessed by assessing their deformability in the actual load condition.

\section{Documentation evaluation}

In order to determine not only the direct but also indirect reasons for the lack of the expected effect of strengthening the subgrade with a protective layer, and the potential responsibility of participants in the construction process, it is additionally recommended to check the design and geotechnical documentation and conduct an interview with the construction management and read the entries in the Construction Diary related to implementation earthworks and the construction of a protective layer.

An important step in the search for the reasons for the lack of full reinforcement effect of the substructure is the control of design and geotechnical documentation. If possible, check the correctness of the design assumptions and the design solutions adopted. In order to obtain design values of the acceptance parameters of the subgrade with a protective layer, it is necessary to adopt a suitable protective layer structure consisting of sub-layers with specified thicknesses and properties and to prepare the substructure as the layer's base. The design should, therefore, include information on the required values of deformation modules and track bed densities before building the layer, the construction of the protective layer and the type and properties of its components and the receiving requirements that the substructure must comply with the protective layer.

In an interview with the construction management and during the inspection of the Construction Diary, particular attention should be paid to:

- occurring during the implementation of adverse weather conditions that may affect the properties of the subgrade land and the building materials used (heat, frost, intense 
precipitation),

- ways of performing earthworks and protective layer, including the equipment used and compaction technology, which may have a negative impact on the properties of the subgrade soil and aggregates of the protective layer.

\section{Remedies in problems with the receipt of the subgrade with a protective layer}

Recognition of the causes of problems with obtaining the required values of the acceptance parameters of the subgrade enables taking appropriate actions aimed at achieving the required subgrade conditions with the protective layer. Six most frequently used methods for improving the bedding properties in such cases have been isolated and described [9-11]. The following methods are distinguished:

- compacting the subgrade,

- improvement of drainage conditions of the subgrade,

- stabilization of the aggregate of the protective layer with hydraulic binders,

- replacement of protective layer aggregate,

- change of the protective layer construction,

- repair of the track bed under the layer.

The choice of the appropriate method should be dictated by the type of the reasons for the lack of the reinforcement effect of the subgrade with a protective layer, the size of the deficit of the acceptance parameters of the subgrade and the availability of technical means. It should also be taken into account that the problems with obtaining the required values of the receiving parameters of the subgrade with the protective layer most often result from a combination of several reasons, and therefore their elimination may require the application of several remedial methods.

\section{Conclusions}

On the basis of the analysis of the reasons for problems with obtaining the required geotechnical parameters of the acceptance parameters after the incorporation of the protective layer, the methods of their identification and elimination, the following conclusions can be drawn:

- Strengthening the subgrade with a system of protective layers encounters difficulties at every stage of implementation: collecting information about the track, preparing a research program and conducting it, performing a reinforcement project and building the layer.

- Indication of one immediate cause and the subject responsible for it in most cases is not possible due to the occurrence of a combination of different circumstances.

- Correct recognition and evaluation of incomplete effects of track bed reconstruction allows for applying appropriate countermeasures of verified equivalent constructions.

\section{Source materials}

[1] Pawłowski M.: Odkształcalność górnej strefy podtorza $\mathrm{z}$ geowłókniną. Przegląd Komunikacyjny 11/2016, s. 15-19.

[2] Pawłowski M.: Próba oszacowania niepewności pomiarowych w badaniach odkształcalności podtorza. Przegląd Komunikacyjny 10/2014, s. 18-20.

[3] PKP Polskie Linie Kolejowe S.A., Id-3. Warunki techniczne utrzymania podtorza kolejowego. 2009.

[4] Siewczyński Ł.: 10 lat modernizacji podtorza w PKP. Materiały sesyjne z Sesji Naukowej „Nawierzchnie kolejowe dla dużych prędkości” z okazji 45. lecia pracy naukowej oraz 70. lecia urodzin Prof. dr hab. inż. H. Bałucha, Gdańsk 25.10.2002, str. 133-142. 
[5] Siewczyński Ł.: Problemy modernizacji podtorza odcinka lubuskiego linii kolejowej E20. Materiały Konferencji Naukowo-Technicznej SITK Poznań „Nowoczesne technologie i inżynieria finansowania modernizacji linii kolejowych" Słubice 2003 r., str. 37-51.

[6] Siewczyński Ł., Pawłowski M.: Projektowanie wzmocnień podtorza według jego właściwości. Przegląd Komunikacyjny 10/2014, s. 24-28.

[7] Siewczyński Ł., Pawłowski M.: Projektowanie wzmocnień podtorza z wykorzystaniem wykresów. Zeszyty Naukowo-Techniczne Stowarzyszenia Inżynierów i Techników Komunikacji w Krakowie. Seria: Materiały Konferencyjne. Rok 2014, nr 2 (104), „Nowoczesne technologie i systemy zarządzania w transporcie szynowym”, s. 337-343.

[8] Siewczyński Ł., Pawłowski M.: Przyczyny utrudnień w osiąganiu pełnych efektów wzmocnienia podtorza warstwą ochronną. Archiwum Instytutu Inżynierii Lądowej nr 25/2017. Wydawnictwo Politechniki Poznańskiej, Poznań 2017, s. 357-366.

[9] Siewczyński Ł., Pawłowski M.: Sposoby powiększania efektów zastosowania warstwy ochronnej. Zeszyty Naukowo-Techniczne Stowarzyszenia Inżynierów i Techników Komunikacji w Krakowie. Seria: Materiały Konferencyjne. Rok 2017, nr 1 (112), „Nowoczesne technologie i systemy zarządzania w transporcie szynowym” cz. I. Droga kolejowa, s. 145-154.

[10] Siewczyński Ł., Pawłowski M.: Stabilizacja podtorza dla budowy warstwy ochronnej. Ogólnopolska Konferencja Naukowo-Techniczna „Nowoczesne metody stabilizacji podłoża pod nawierzchnie drogowe i kolejowe", Żmigród-Węglewo 22-23.10.2009 r., s. 111-117.

[11] Siewczyński Ł., Pawłowski M.: Stosowanie równoważnych konstrukcji wzmocnień górnej strefy podtorza. Zeszyty Naukowo-Techniczne Stowarzyszenia Inżynierów i Techników Komunikacji w Krakowie. Seria: Materiały Konferencyjne. Rok 2016, nr 2 (109), „Nowoczesne technologie i systemy zarządzania w transporcie szynowym” cz. I. Droga kolejowa, s. 137-146.

[12] Siewczyński Ł., Pawłowski M.: Wymagane i osiągane wartości wskaźnika odkształcenia modernizowanego podtorza. Zeszyty Naukowo-Techniczne Stowarzyszenia Inżynierów i Techników Komunikacji w Krakowie. Seria: Materiały Konferencyjne. Rok 2005, nr 73, z. 124 ,Nowoczesne technologie i systemy zarządzania w transporcie szynowym”, str. 245-264. 